\title{
Les aliments ultra-transformés, un concept utile pour la santé publique
}

\author{
Ultra-processed foods, a useful concept for public health
}

\author{
Louise Potvin ${ }^{1}$
}

Published online: 8 January 2019

(C) The Canadian Public Health Association 2019

Nous publions dans ce numéro un article qui introduit le concept d'aliments ultra-transformés et la relation qui existe, à l'échelle des populations, entre la consommation de ces aliments et l'obésité. Ce concept est relié à une échelle d'appréciation du degré d'industrialisation des aliments de consommation courante, l'échelle Nova qui a été introduite depuis une dizaine d'années à travers les travaux de l'équipe de Carlos Augusto Monteiro au Brésil (Monteiro 2009). Il s'agit d'un concept et d'une échelle intéressants et des plus pertinents qui permettent d'établir des liens entre les systèmes alimentaires mondiaux, la nutrition et la santé publique pour guider les consommateurs dans leurs choix alimentaires.

Depuis des dizaines d'années, les nutritionnistes ont décomposé et analysé la diète des Canadiens et proposé des directives, sous forme d'un Guide alimentaire (révisé périodiquement), pour soutenir les efforts des Canadiens pour s'alimenter correctement. Les premières versions de ce Guide reposaient sur la proposition fondamentale que les différents nutriments qui sont présents dans la nourriture sont métabolisés de la même manière quel que soit l'aliment dans lequel on les retrouve; un glucide est un glucide et une calorie est une calorie. L'identification et la classification de ces nutriments permet de distinguer et classer les aliments en fonction de leur apport à une diète équilibrée. On peut ainsi proposer qu'une alimentation « saine » devrait comporter plus de viandes blanches et de poissons que de viandes rouges puisque que le ratio calorie/protéine est plus élevé dans la viande rouge que dans le poisson ou les viandes blanches. Mais cette prémisse mène aussi naturellement à la conclusion que consommer le jus d'une orange, sans sucre ajouté, a la même valeur nutritive en vitamines et glucides que de manger l'orange. On sait maintenant que c'est en grande partie faux et certains avancent même que les directives du Guide

Louise Potvin

louise.potvin@umontreal.ca

1 École de santé publique et Institut de recherche en santé publique, Université de Montréal, Montreal, QC, Canada alimentaire canadien pourraient être en partie responsables de l'épidémie d'obésité actuelle (L'Abbé 2015). Outre le fait que l'utilisation responsable d'un tel guide demeure complexe, les humains ne consomment pas des nutriments mais des repas et des aliments qui composent une diète, et ces aliments sont formés de plusieurs composantes qui interagissent. C'est sur la diète en entier et les sources d'approvisionnement qui rendent une diète possible que devrait porter l'analyse d'un point de vue de santé publique. Ce qui complique considérablement l'exercice qui consiste à faire des recommandations nutritionnelles pour une population. Il faut de toute évidence considérer les aliments dans leur ensemble et adapter les recommandations en fonction des différents segments de la population.

La classification Nova, développée par Monteiro et ses collaborateurs, introduit une autre dimension à la question de nourrir sainement une famille ou une population, mais cette dimension pourrait éventuellement réduire grandement la complexité des messages. Selon eux, la forme sous laquelle se présentent les nutriments dans les aliments et qui est liée aux procédés industriels de décomposition des aliments et leur recomposition pour en modifier certaines caractéristiques (dont la conservation), altère la manière dont ils sont métabolisés dans l'organisme. Comme Nardocci et ses collaborateurs l'expliquent dans leur article (Nardocci et al. 2019), la classification distingue quatre groupes d'aliments (Moubarac 2017). Le premier groupe comprend les aliments non transformés ou minimalement transformés que sont les produits végétal ou animal dans lesquels on n'introduit aucune substance ou qui font l'objet d'un traitement minimum comme la pasteurisation. On y retrouve le lait, les légumes, légumineuses, fruits, viandes et poissons frais, congelés ou déshydratés. Ce sont les aliments que l'on devrait consommer de préférence. Le second groupe comprend les ingrédients culinaires transformés comme les huiles, le sucre et les corps gras, ou obtenus naturellement comme le sel. Leur principale utilité est d'être amalgamés dans des recettes avec des aliments non transformés, pour constituer des mets cuisinés. Le troisième groupe est constitué d'aliments transformés par des 
procédés industriels qui amalgament des aliments des deux premiers groupes sans toutefois y ajouter des additifs ou en décomposer industriellement les molécules. On y retrouve le fromage, le pain intégral, et divers autres produits végétal ou animal. Le quatrième groupe est composé des aliments ultratransformés qui ne contiennent à peu près pas d'aliments intacts. Ceux-ci sont soumis à divers procédés industriels ou sont amalgamés avec divers additifs qui en modifient les propriétés pour les rendre plus pratiques (ils se conservent plus longtemps), attrayants (ils se consomment facilement et sont en général plus sucrés ou salés) et profitables (ils contiennent souvent, à la base, des ingrédients bon marché).

L'étude publiée dans ce numéro (Nardocci et al. 2019) se situe dans la lignée de dizaines d'autres études conduites dans des pays industrialisés et en Amérique latine et qui démontrent que la consommation d'aliments ultra-transformés est associée avec la prévalence de l'obésité. Sans surprise, cette étude montre aussi que les hommes, les personnes plus jeunes, les personnes qui fument, qui sont moins actives physiquement et qui sont moins éduqués sont aussi plus susceptibles de consommer plus d'aliments ultra-transformés.

Bien sûr, il faudra encore plusieurs études, dans plusieurs pays et comportant des aspects longitudinaux pour que l'utilité de la classification Nova soit bien établie et généralisée, mais les perspectives qu'elle ouvre sont très intéressantes et pourraient donner lieu à une classification très simple pour guider les choix des consommateurs aux points de vente. Un code vert pour des aliments minimalement transformés signalerait que l'on peut en consommer à satiété, un code orange pour les ingrédients culinaires transformés et les aliments transformés signalerait une recommandation de consommation modérée, et un code rouge pour les aliments ultratransformés indiquerait qu'il est préférable, d'un point de vue de santé publique, de s'abstenir d'en consommer. Le système est simple et produit un message facilement décodable. Bien sûr, l'implantation d'un tel système rencontrerait probablement des résistances féroces de la part de l'industrie agro-alimentaire, mais ce serait l'occasion de mettre en pratique les leçons tirées de la lutte contre le tabagisme.

Louise Potvin, Ph.D.

Rédactrice-en-chef

\section{Editorial}

In this issue, we publish an article that introduces the idea of ultra-processed foods and the relationship that exists at the population level between the consumption of these foods and obesity. This concept is tied to a rating scale (Nova) of the degree of industrialization of foods eaten today. The Nova scale was introduced about 10 years ago through the work of Carlos Augusto Monteiro's team in Brazil (Monteiro 2009). It consists of a most pertinent and interesting concept and scale that provide for the establishment of links between the world's food systems, nutrition, and public health, to guide consumers in their food choices.

For decades, nutritionists have broken down and analyzed the Canadian diet and have proposed guidelines, in the form of a Food Guide (periodically revised), to support the efforts of Canadians to eat properly. The earliest versions of this Guide were premised on the fundamental proposition that the various nutrients in the food are all metabolized in the same way regardless of the food in which they are found. A carbohydrate is a carbohydrate and a calorie is a calorie! The identification and classification of these nutrients allow us to differentiate and classify foods based on their contribution to a balanced diet. It could then be suggested that a "healthy" diet ought to have more white meats and fish than red meats because the calorie/protein ratio is higher in red meat than in fish or white meat. But this premise also naturally leads to the conclusion that consuming the juice of an orange, with no sugar added, has the same nutritional value in vitamins and carbohydrates as eating the orange. It is now known that, in large part, that is false and some even suggest that the guidelines in the Canadian Food Guide could, in part, be responsible for the epidemic of obesity (L'Abbé 2015). In addition to the fact that the responsible use of such a guide remains complex, people do not consume nutrients but rather the meals and foods that make up a diet, and these foods are formed from many components that interact. From a public health point of view, dietary analysis must be based on a diet in its entirety and the supply sources that make a diet possible. What complicates the matter considerably is the need to make nutritional recommendations for a population. Clearly, one must consider foods in their entirety and adapt recommendations according to the different segments of the population.

The Nova classification, developed by Monteiro and colleagues, introduces another dimension to the matter of the wholesome nourishment of a family or a population, but this dimension could eventually greatly reduce the complexity of the messages. According to these researchers, the way in which nutrients are presented in foods, which is linked to the industrial processes of breaking down and then reconstructing them to modify some characteristics (such as preservation), alters the way in which they are metabolized in the body. As Nardocci et al. explain in their article (Nardocci et al. 2019), the classification differentiates four food groups (Moubarac 2017). The first group includes non-processed or minimally processed foods that are animal or vegetable products, into which no other substance is introduced, or which are lightly processed, such as through pasteurization. This would include milk and fresh, frozen, or dehydrated vegetables, legumes, 
fruits, meats, and fish. These are the preferred foods that one should eat. The second group includes processed culinary ingredients, such as oils, sugar, and fats, or ones that are obtained naturally like salt. Their main use is to be included in recipes with non-processed foods to make cooked dishes. The third group is composed of industrially processed food that is made up of foods from the first two groups without introducing additives or industrially breaking down molecules. This would include cheese, whole bread, or various other animal or vegetable products. The fourth group is made up of ultra-processed foods that contain almost no intact foods. These are subjected to various industrial processes or are combined with various additives that modify their properties to make them more practical (their shelf-life is increased), attractive (they are easy to eat and are generally sweeter or saltier), and profitable (basically, they often contain cheap ingredients).

The study published in this issue (Nardocci et al. 2019) is in line with dozens of other studies conducted in industrialized countries and in Latin America, which demonstrate that the consumption of ultra-processed foods is associated with the prevalence of obesity. Not surprisingly, this study also shows that men, younger individuals, people who smoke, who are less physically active, and who are less educated are also more susceptible to eating more ultra-processed foods.

Of course, more studies are needed, in many countries and including longitudinal design in order for the usefulness of the Nova classification to become well established and generalized. However, the perspectives they open are very interesting and could give rise to a very simple classification to guide consumer choices at point of sale. A green code for minimally processed foods would indicate that they could be eaten to satiety; an orange code for processed culinary ingredients and processed foods would signal a recommendation of moderate consumption; and a red code for ultra-processed foods would indicate that, from a public health point of view, it is better to abstain from eating them. The system is simple and provides an easily decodable message. Certainly, the implementation of such a system will probably meet with fierce resistance from the agri-food industry, but it will be an opportunity to put into practice lessons learned from the fight against tobacco.

Louise Potvin, $\mathrm{PhD}$

Editor-in-Chief

Publisher's Note Springer Nature remains neutral with regard to jurisdictional claims in published maps and institutional affiliations.

\section{Références bibliographiques /References}

L'Abbé, M. (2015). Canada's food guide promotes obesity - we need change now. U of T Medicine Magazine. Downloaded on December 92018 from: https://medicine.utoronto.ca/magazine/ article/food-guide

Monteiro, C. (2009). Nutrition and health. The issue is not food, nor nutrient, so much as processing. Public Health Nutr, 12, 729-731.

Moubarac, J. C. (2017). Ultra-processed foods in Canada: consumption, impact on diet quality and policy implications. Montréal: TRANSNUT, University of Montreal Available at: http://www. heartandstroke.ca/-/media/pdf-files/canada/media-centre/hs-reportupp-moubarac-dec-5-2017.ashx.

Nardocci, M., Leclerc, B-S., Louzada, M-L., Monteiro, C. A., Batal, M., Moubarac, J-C (2019). Consumption of ultra-processed foods and obesity in Canada. Canadian Journal of Public Health, 110, https:// doi.org/10.17269/s419 